\title{
FÜZY Annamária
}

\section{AZ ÚJ GENERÁCIÓS TUDÁSMENEDZSMENT ÉS SIKERÉNEK ZÁLOGA}

Miben rejlik egy szervezeti tudást támogató informatikai projekt sikere? Milyen új eszközök állnak rendelkezésre napjainkban a tudás megragadására és elérhetővé tételére? A 2.0-ás forradalom elérte a tudásmenedzsment-eszközöet is. Korunk nagy szervezeteiben a tanulási képesség vált a tartósan fenntartható versenyelónyök fó forrásává, így ezzel párhuzamosan a hatékony megvalósításhoz szükséges információtechnológiai megoldások is elótérbe kerültek. Az IT azonban csak közvetetten képes hatni a szervezet versenyképességére, a szervezeti tanulás támogató funkciójaként. A cikk célja a tudásmenedzsment-rendszerek újabb formáinak bemutatása, illetve ezen rendszerek sikertényezóinek vizsgálata.

Kulcsszavak: tudásmenedzsment, web 2.0, információtechnológia (IT)

„Where is the knowledge we have lost in information?"

T. S. Eliot: Choruses from „The Rock"

AXX-XXI. század fordulójára a technológia fejlődése új helyzetet teremtett: a gyorsuló piaci változások, az intelligens termékek és a személyre szabott szolgáltatások meggens termékek és a személyre szabott szolgáltatások megjelenése, valamint a globalizáció kovetkezteben a szervezetek meglévó tudása és tanulási képessége vált a tartósa fenntartható versenyelónyök fố forrásává. A világban folytonosan tanuló szervezetek hálózatai alakulnak ki (Gelei, 2002). A tóke szerkezete is változik, a materiálistól az immateriális felé tolódik el (Baruch, 2004).

Korunk nagy szervezeteiben a változások többségének van valamilyen információtechnológiai (IT) vonatkozása (Markus, 2004). Az informatikai projektek hibaszázaléka azonban messze meghaladja a hagyományos alaptevékenységi technológiák bevezetéséne tapasztaltakat. A menet közben feladott, illetve a befejezett, de soh. A menctión a befejezett, de sohasen nán jelentôs. Figyelembe véve, hogy az üzleti világ szermatikára, a kár, amely az informatikai projektek rossz matikára, a kár, amely az informatikai projektek ross teljesítésébôl ered, jelentós összeget tesz ki (Dahler. 2005). A kockázat a legújabb technológiák esetében legjelentősebb - ezek közé tartoznak a szervezeti tanulást segító alkalmazások is. Az ilyen projektek vizsg lata ezért különös figyelmet érdemel mind technológi szempontból, mind a változásvezetési mechanizmusok szempontjából (Martensson, 2000; Fekete, 2002 Herschel et al., 2005; Jewels et al., 2006).

Az IT versenyelônyt biztosító képessége már a 80-as évek óta ismert mindenekelótt Wiseman (1988) nagy sikerú könyve révén. Az IT azonben nem közvetleniil ha a szervezet verenyépessécére, hanem valomilyen átételen kesziil A korábbi technógiäzzon áté let eltólik oly áj aspek let eltolódik olyan új aspektusok vizsgálatának irányába 1988). Az IT jzervezeti tanuás és tudás (Zuboff, 1985 1988). Az IT jelenléte, az információforrásokhoz való korlátlan hozzáférés megteremtése ugyanis önmagában nem ad választ a kihívásokra. Az igazán nagy feladat a rendelkezésre álló tudásvagyon feltárása és rendszerezése, illetve a kommunikációs csatornák és kapcsolatrendszerek kiépítése (Martensson, 2000). Természetesen ehhez az egyéni és szervezeti feltételeken túl további kiegészítô IT-rendszerek is szükségesek lehetnek. Bár a mesterś́ges intelligencia ïzleti alkalmaźsa terén évtizedek óta csekély elórehaladás tapasztalható az új technológiák nagy száma és heterogenitása azt jelzi, hogy a kísérletezés folyik, még ha az ideális megoldás nem is született meg (Laszlo et al., 2002).

A szervezeti tanulás és tudás információtechnológiával való támogatása, valamint ezek hatása a szervezet alkalmazkodóképességére olyan kutatási terület, ahol még számos kérdés vár megválaszolásra. Elemzésem célja annak áttekintése, hogy milyen fejlődési mecha- nizmuson ment keresztül a tudásmenedzsment az elmúlt évtizedben, illetve milyen tényezók határozzák meg a szervezeti tudással és tanulással kapcsolatos informatikai projektek sikerét vagy kudarcát.

\section{Szervezeti tanulás, tanuló szervezet}

A szervezeti tanulás olyan folyamat, amelynek sorá tudás jön létre. Olyan tudás, amely elterjesztésre keriul a szervezetben, sốt beépül a szervezet memóriájába, íg késóbbi döntésekhez is elérhetővé válik. A folyama eredményeként kibőviül a lehetséges viselked́s folyam eredrín veli tagok magatartásána változását, ezen keresztül pedig a környezethez jobba illeszkedô szervezetek létrejöttét. A szervezeti tanulás mindenképpen valamilyen változáshoz kapcsolódik, lényege a rejtett (tacit) és kifejezett (explicit) tudás adása a tagok interakciója révén (Nonaka, 1994).

A gyors környezeti változások közepette a hosszú távú fennmaradás egyedüli lehetséges útja a sikere alkalmazkodás. Az élenjáró szervezetek külső feltételrendszerüket állandóan szem elốtt tartva, ahhoz rugalmasan igazodva alakítják ki felépítésüket és folyamataikat, sốt esetenként preaktív módon elébe is mennek környezeti változásoknak (Dobák, 1996). Ez a képesség csak a hagyományostól eltér", kreatív szervezeti ség csak a hagyo

Az ún. Tamuló szervezetek azok, amelyek a szervezeti tagok elkötelezettségére és önmegvalósítási szük-

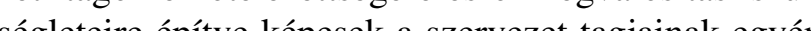
tudását ko létrehozni. Az infor sezzed szenvezeti szinten uj tudást létrehozni. Az információs forradalom magával hoz azt a változást, hogy gyakorlatilag „,valós idóben” lehet tetszóleges mennyiségú és minôségú információhoz hozzájutni. Az információrobbanás azonban önmagában még nem jelent több tudást, és a hagyományos szervezetek általában nem is tudnak élni e lehetôséggel. A tanuló szervezetekre ezzel szemben jellemzó a szisztematikus problémamegoldás, a saját tapasztalatokból való tanulás, a mások által nyert tapasztalatok fése (Garvin, 1993). Ha egy szervezt javís elterjesztése (Gavin, 193). Ha egy vala tanulasi képességé, ezen az ơ teruleten érdemes váltoti és technológiai elemekre egyaránt ki kell terjedniük.

A jelenlegi tudásmenedzsment-rendszerek

A szervezetek szellemi vagyonuk összegyújtésére, rendszerezésére és a szervezeti tagok közötti terítésére egyre több IT-alapú tudásmenedzsment-rendszent hoznak létre. Az utóbbi évek IT-beruházásai lehetôvé tették a vállalatok számára az egyre hatékonyabb tudásgenerálást, az intranettechnológiák megjelenése pedig felgyorsította a tudásmegosztás folyamatát - bár számos esetben a különböző részelemek (fájlszerverek, speciális szövegtárak, intranetrendszerek stb.) egymástól elzártan, függetlenül múködnek. Egy-egy munkacsoport számára hasznos segédeszközt jelentenek, de sokszor rejtve maradnak a szervezet többi tagja elól. A sokszínú és általában szigetszerúen múködő rendszerek következtében az információhiány és az informácios túlterheltség egyformán gondot okozhat.

Az AMR Research által 2005-ben mintegy 400 ITvezetố részvételével készített kutatás kimutatta, hogy vállalatok IT-költségvetésük 50-60\%-át az információk előállításával, feldolgozásával és megosztásával kapcsolatos alkalmazásokra költik. Ezen belül 7,6\%-ot pedig kifejezetten tudásbázisokra fordítanak (Murphy Davis, 2005). E fejlesztések megtérülése ugyanakkor kérdéses, mert a tudáskezeló rendszerek többsége ma még nem a második generációra jellemző emberközpontú értékekkel bíró, egyéni kialakítást lehetővé tevố technológiákon alapul

Számtalan olyan alkalmazás hódított teret magának az utóbbi idốben, amely bár hatékonyan támogatja a tudáskezelést, mégis túlzás lenne teljes értékú tudáskezelố rendszernek nevezni - legyen szó akár int ra csopory stón cesk vay a

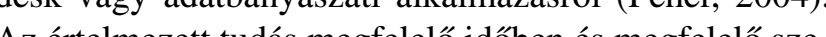
Az êrtelmezett tudás megfelelố idôben és megfelelô szeểyhez való eljuttatása - e csatornákon keresztül - jó glgoritmizálható feladat. Viszont az ezt követố hasznositás és tanulás olyan folyamatok, amelyeket nem lehet egzakt lépések sorozataként leírni. Elemzók szerint évek telhetnek el, amíg a piacon megjelenik az első, valóban minden jelenlegi elvárásnak megfeleló, komplex tudáskezelő rendszer (Martensson, 2000; Gartner 2001).

\section{Mit hoz a második generáció}

Az utóbbi idóben mind a szakirodalomban, mind a gyakorlatban egyre népszerúbb a tudásmenedzsmentrendszerek két generációjának megkülönböztetése. A következókben ezeket mutatom be, illetve hasonlítom össze.

\section{KM 1.0"}

A számarányukat nézve máig domináns korai tudásnenedzsment-rendszerek - mint például a dokumentumezelók - elsôsorban az explicit tudásra koncentrálnak. Ezek az ún. technológiaközpontú alkalmazások a 90-es evektôl kezdtek elterjedni, fó komponenseinket az adat- 
bázis-kezelő rész és a keresômotor képezi. Fókuszukban a rosszul strukturált információ menedzselése és a keletkezett tudás megosztása áll. Elsősorban a földrajzilag távoli helyek közötti tudásáramlást szolgálják. A felhasználók gyakran nem látják a tudásbázisban rejlő értékeket,
ezért e rendszerek bevezetése vagy hosszabb idôszakon ezért e rendszerek bevezetése vagy hosszabb idôszak keresztüli fenntartása könnyen kudarcba fulladhat.

,KM 2.0"

Miközben a szervezetek többsége a technológiaközpontú tudásmenedzsment-rendszerek bevezetésével foglalkozott, a 90-es évek közepétól megjentek aze foglalkozot, a gu-eś évek közepetól megjelentek az emberkópont a lyek már lehetố tettek a személyek közötti közvetle tudásmegosztást. E rendszerek kiscertet terepei mindenekelött az ún. szakmai közösségek (Communities of
Practice) voltak, amelyek tagjai azért szerveződnek Practice) voltak, amelyek tagjai azért szerveződnek
csoportokba, hogy a birtokukban lévő tudást megosszák csoportokba, hogy a birtokukban lévő́tudást megosszák egymással. A cél itt már nem elsősorban a hatékonyság, hanem az informális tanulás, az együttmúködés, s ezátal a döntéshozatal, az innovációk és a kreativitás elốsegítése. Az itt alkalmazott eszközök - mint pl. a peerto-peer networking (hatékony fájlcserék megvalósítása az interneten keresztül szabad hozzáférésú tárhelyek segítségével), az értelmezések (narratives), az emlékeztetók (retrospects), a tudás-kávézók (knowledge café) - lehetővé teszik a tudás újrafelhasźńáćt és kin-

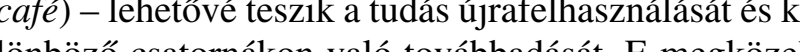
tés alapvetố eltérése a korábbiakhoz képest a kérdésfeltevés alapvetón irányának megvéréltoztatása már nem az számít, hogy a tudás már nem az számít, hogy a tudás szervezetet, hanem hogyan építsünk fel olyan szervezetet, amely elósegíti a tudásfolyamatokat.

Napjainkban tehát a tudásmenedzsment-alkalmazások már nemcsak a tudásra fókuszálnak, hanem törekednek az emberek közötti kapcsolatok, közösségek létzú tris az j, tús jollogr szantogépes mint pl. a blog (webnapló) vagy a wiki (szabad tartalomszerkesztést biztositó webhely)
- továbbra is szöveges és kódalapú, így még mindig in- továbbra is szöveges és kódalapú, így még mindig inkább az explicit tudásra koncentrál, a korábbiakhoz képest már jóval strukturálatlanabb, önfejlesztő megközelítést képvisel a tudás felderítésében és megosztásában. A másik fontos különbség a „tradicionális” technológiákhoz képest, hogy míg azokat a nagy szoftvergyártó cégek fejlesztették ki, ezen eszközok legtöbbje szabad

A tudásmenedzsment generációk összehasonlítása 作 colón

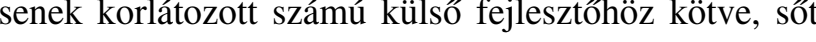
gykran maguk is képesek a rendszer kialakitására és ennek revén a rendszer testre szabása is gyszerúbb, mivel a közremúködôk egy olyan közösség tagjai, amelyhez önént csatlakoztak, épp a hatékony tudásmegosztás érdekében. Új jelenség, hogy ezek a közösségek már nemcsak anonim módon, az interneten szerveződnek, hanem a formális szervezeti keretek köJott is egyre több van belólük. Ma már nem ritkaság, ha y vezeto" ,blogol" és egyre-más épülnek a corporate

Az önszerveződő modellek létrejöttével a tudásmedzsment már nem egy központi szervezeti funkció, sokkal inkább a szervezeti tagok mindennapi munkájának integráns része (Móricz, 2008). A tudás már nem központilag ellenőrzött, hisz mind a tulajdonjog, mind a kontroll a szervezeti tagok kezében van. Megjelennek az olyan szociális kapcsolati hálók, mint az $i W i W$, vagy Facebook, ahol a szabad tartalomszerkesztésen, audiovagy videofájlok megosztásán kívül lehetőség van különbözó internetes csoportokhoz is csatlakozni. Az e-mail mellett elótérbe kerül az Instant Messaging mely a valós idejú kommunikációt segíti elô szöveges formátumban. friss hírekról az RSS (Really Simple Syndication) Feed 'évén értesiliink mely egy specílis program a killïbözố weboldalak tartalmának szúrt megjelenítésére.

\section{(Gurteen, 2007)}

\begin{tabular}{|c|c|}
\hline KM 1.0 & KM 2.0 \\
\hline $\begin{array}{l}\text { - Vállalat által meghatározott } \\
\text { - Top down - irányú } \\
\text { - Centralizált } \\
\text { - Parancs és kontroll } \\
\text { - Hierarchikus rendszer } \\
\text { - Explicit tudás megosztása a cél }\end{array}$ & $\begin{array}{l}\text { - Személyes hozzájáruláson alapul } \\
\text { - Bottom up - irányú } \\
\text { - Decentralizált } \\
\text { - Hatalom a felhasználók kezében } \\
\text { - Önszervezödö } \\
\text { - Tacit tudás kinyerése a cél }\end{array}$ \\
\hline
\end{tabular}

A tudásmenedzsment sokat változik napjainkban, mi a korábban tárgyalt külső környezeti hatásokon kívül olyan belsố szervezeti tényezôknek is köszönhetố, mint pl. a támogató vezetés, a nyitottság és a kísérletezés. A felülrôl lefele tortenó irannyítás helyébe egyre inkább a lentról felfelé irányuló folyamatok lépnek, az empowerment kezdeményezések révén a tudáshatalom a felhasználók kezébe kerül

VEZETÉSTUDOMÁNY

A tudásmenedzsment-kezdeményezések sikertényezôi

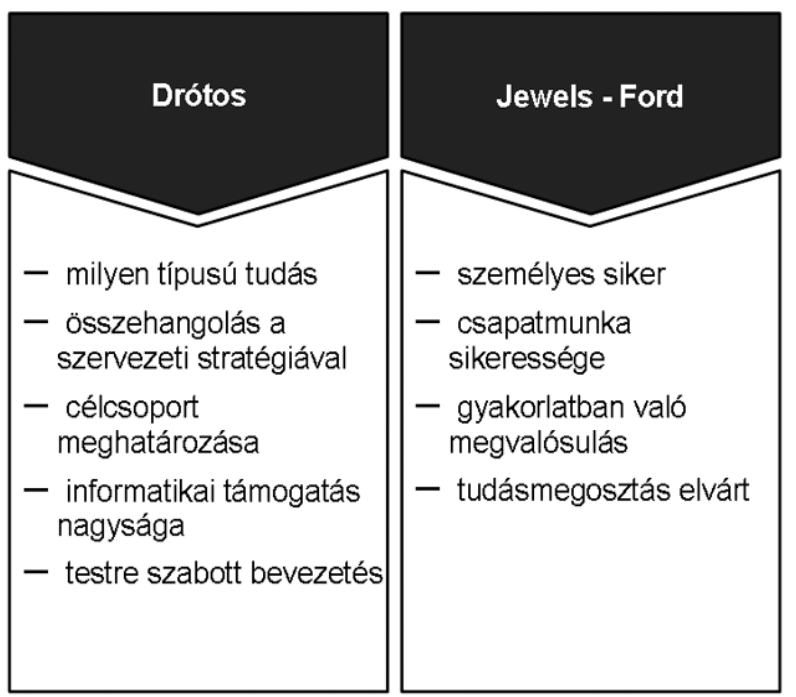

Ugyanakkor a második generációs technológiák önszervezôdó jellegúkbool adódóan - olyan dilemmákat is felvetnek, mint a bizalom és a biztonság kérdése a tudásmegosztásban, hiszen a szabad hozzáférés növeli visszaélés kockázatát. A személyes hozzájáruláson alapuló tartalomszerkesztés esetében pedig a tulajdonjogok tisztázatlanságának problémája merül fel (1. ábra).

A tudásmenedzsment-kezdeményezések sikertényezői

A legtöbb szervezet tudásmenedzsment-rendszerének bevezetésekor elvész a technológiai problémák és az output elvárások dilemmáinak sứrújében, s elfelejti a tudáshoz vezetô út végiggondolását. Ez pedig nemcsa azért lenne fontos, mert ezeket a rendszereket is emberek használják majd, hanem mert épp ôbennük szeretnénk változásokat elóidézni. A tudáskezelô alkalmazások sikere tehát sokban múlik a tanulás természetének megértésén és a folyamatszemléleten.

A gyakorlat mindenesetre nem azt mutatja, hogy pontosan ismernénk e tényezóket. A Gartner Group informatikai szakértók részételével végzett felmúrés azt mutatta ki, hogy a tańcsodóipa kivételével ásztvevó mind sikertelennek tartották tudásmenedzsmentprogramjuk (Gat 2001). A túcs válasza (Gán 23\%, 2001). A tanácsadók 75\%-ânak igen a perza a pénzügyi szakértốk következtek, míg alig 2\%-kal az államigazgatás zárta a sort. A vizsgálat konklúziója szerint a tudásmenedzsment-kezdeményezések innováció kockázata igen nagymértékú, amelynek szintje azonba csak hosszabb időtáv elteltével állapítható meg objektívan, mivel a tudásmenedzsment-rendszerek megtérülé se ideális esetben is csak több év elteltevel jelentkezik.

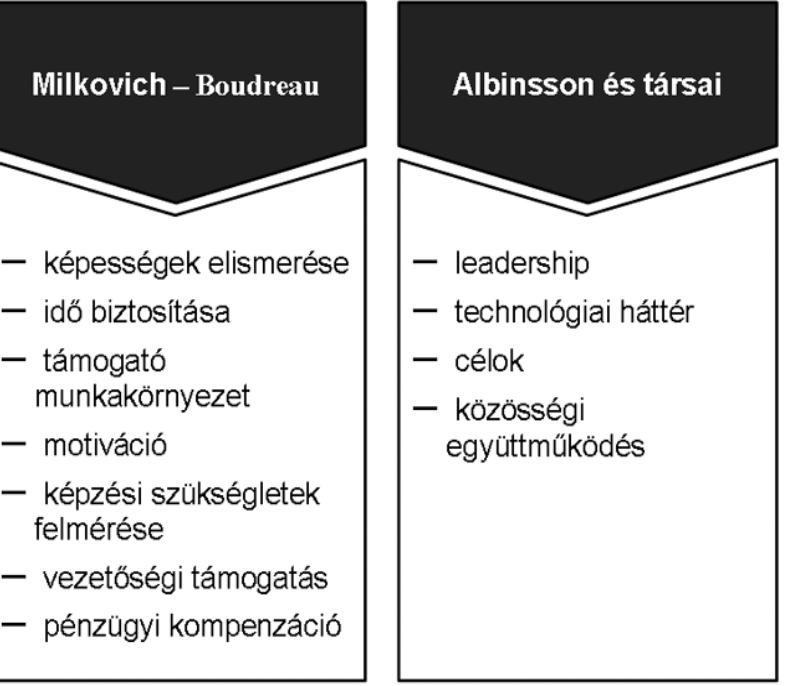

A kockázat enyhítése céljából ezért nem a befektetés megteruulesét (ROI), hanem értékét (VOI) kell néznünk. Elemzésem további részében szakirodalmi források alapján a tudásmenedzsment-kezdeményezések sikertényezőinek áttekintését végzem el, különös tekintettel a második generációs alkalmazásokra (2. ábra).

Drótos (2006) szerint öt kulcsfontosságú lépést különböztethetünk meg az ilyen típusú problémák kezelésére. Először is fontos megállapítani, hogy pontosan milyen típusú tudásra, illetve a tudáskonverziós ciklus mely pontjaira akarunk koncentrálni. A tudásmenedzsment-kezdeményezéseket össze kell hangolni a szervezeti stratégiával, majd meg kell határozni a célcsoportot (egyén-csoport-szervezet), valamint az informatikai támogatás mértékét. Végül pedig testreszabott rendszerfejesztési és bevezetési eljárások alkalmazása szükséges. A tudásmegosztást befolyásoló faktorok közül kiemelkedő lehet a tudásmunkások motivációja és elkötelezôdése (Malhotra - Galleta, 2003). Ezt támasztja alá Jewels és Ford 2006-ban végzett kutatása is, amely szerint a tudásintenzív iparágak vállalatainak tudásmegosztásához a személyes siker, a csapatmunka sikerescége és a gyakoratban való megvá́sús jelenti a fö motiváló

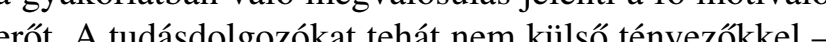
pénzbeli juttásokkal vagy pozíciójuk fenyezetétsé vel - kell motiválni. Inkább az a fontos, botey lágá e nin a mos , hogy lássák, amint a megosztott tudás a projekt, és ezáltal a csapat sikeréhez vezet. Emellett fontos, hogy az érintettek érezzék, hogy a tudásmegosztás elvárt tólük, a vállalat sikere múlik rajta. Összefoglalva tehát az egyének tudásmegosztási hajlandóságának növelése szempontjából kiemelkedő fontosságú az egyéni és projektcélok, illetve az egyéni és a szervezeti célok összehangolása. 
További kritikus sikerdimenziók, melyek befolyásolására hangsúlyt kell fektetni a fejlesztési folyamat sorá (Milkovich - Boudreau, 1988) az új képességek, ismeretek elismerése, a megfelelő idó biztosítása a program elvégzésére, az új, tanult viselkedés megerősítése a munkakörnyezetben, a résztvevók motivációjának fenntartása, a képzési szükségletek pontos felmérése és nyomo követése a program lefolyása közben, a vezetés elkötelezettsége, végül a megfelelő pénzügyi kompenzáció.

Albinsson és társai empirikus kutatása (2007) szintén azt vizsgálta, hogy hogyan hozzunk létre és tartsunk fenn sikeres tud́́s fenn siké közösségekben. Arra a megallapitasra jutottak, hogy inkább az olyan nem technikai jellegú aspektusokr kell koncentrálni, mint pl. a leadership, a kultúra, a társadalmi-szociális helyzet vagy a részvétel értékelése. Ugyanakkor ezek még mindig csak szükséges, de nem elégséges feltételek a sikerhez. A technológiai hátté ezen belül a rendszerfejlesztés és -testreszabás vagy az intellektuális tốke megosztásának jogi kérdései talán kevésbé túnnek érdekesnek a résztvevốk szempontjâból, ámde nem kevésbé jelentôsek. Az is fontos, hogy a sikeres együttmúködés biztosítékai már a közössé kialakulásától kezdve adottak legyenek. A közösség egyénre gyakorolt pozitív benyomása azért fontos, mert a bizalom elvesztése után az egyén nem ad második lehetőséget a „rendszernek”.

\section{Konklúzió - lépünk-e egyról a kettoóre?}

A szakirodalmi statisztikák vizsgálata egyértelmúe igazolja, hogy az elmúlt években a tudásmenedzsment tudományos érdeklődés középpontjába került. De vajo beváltja-e a hozzá fúzött reményeket? Vagy a hason menedzsmentdivatokkal együtt eltünik a süllyesztóben?

A külső piaci tényezók által generált tudásmenedzsment-rendszerek első generációja a rosszul strukturál információ megragadására koncentrált, vagyis arra, hogy az a szervezeti tagok számára kereshetôvé és szếles körben elérhetôvé váljon. Az első generációs projektek kudarcábon nagy szerepet játszott a szervezojektek (a)

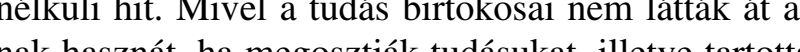
nak hasznát, ha megosztják tudásukat, illetve tartottak a tudás kizárólagos birtoklásából származó hatalmi pozíciójuk elvesztésétốl, a tudáskezeló rendszerek vagy ki sem épültek a terveknek megfelelóen, vagy gyorsa elsorvadtak múködésbe állásuk után

A technológia fejlódésével a rendelkezésre álló információ mennyisége is robbanásszerúen megnốt. A szervezeteknek már nemcsak a strukturált adatokat kell kezelniuk, hanem a nem strukturalt dokumentumo- kat, audio és vizuális elemeket, szóbeli információkat is. A szervezeti tudás négyötöde pedig jellemzóen ilyen "ormátumú".

A második generációs tudásmenedzsment-rendszerek eljövetele együtt járt az önszerveződő közösségek kialakulásával a határok nélküli világhálón éppúgy, mint a formális szervezeteken. Ezekben a közösségekben már nem az a kérdés, hogy hogyan vesszük rá a tagokat a tudás megosztására, sokkal inkább az, hogy milyen módon osztjuk meg a tudást, hogyan tanulunk és dolgozunk együtt.

A tudásmenedzsment-kezdeményezések sikere neheen képzelhetố el megfelelő technológiai háttér nélkül, de alapvetően együttmúködő vezetési stíluson és biztos vállalati kultúrán alapul. Emellett nélkülözhetetlen az egyén beavatása a vállalati folyamatokba, hogy lássa az általa rendelkezésre bocsátott tudás hasznosulását.

A $100 \%$-os siker még a fent említett tényezók figyelembevételével sem garantálható. A tudásmenedzsment-rendszerek bevezetésekor érdemes számításba venni a Gartner Group elórejelzéseit, miszerint 2012re a szervezeteknek 30-szor akkora mennyiségú információt kell kezelniük, mint 2002-ben - így a releváns tudáshoz vezető út megtalálása még nehezebbé válhat (Gartner, 2002). Vajon teljesülni fog-e ez a merész elôrejelzés? És ha igen, vajon hogyan birkóznak meg vele rejere szzerve A köv? Nos, az emlitett ion a fennmaradó időszakban.

\section{Felhasznált irodalom}

Albinsson, L. - Curtin, G. - Forsgren, O. - Wall, M. (2007): Creating and Sustaining Successful Knowledge Management in Purposeful Communities

Baruch, L. (2004): Az immateriális javakban rejlő versenyelóny fokozása. Manager Magazin, december, 39-47. o. obák M. és munkatársai (1996): Szervezeti formák és vezetés, KJK, Budapest

Drótos Gy. (2006): Aldás vagy átok? - Információtechnológia a tudásmenedzsment-kezdeményezésekben. In: Noszkay Erzsébet (szerk.): Megragadni a megfoghatatlant... - Tudásmenedzsment elméleti és gyakorlati megközelítésben, az MTA Vezetés- és Szervezéstudományi Bizottság Tudásmenedzsment Albizottságának gyúijteménye, I. sz. kötete

Fehér P. (2004): Tudásmenedzsmentet támogató tényezók szerepe a tudásintenzív cégeknél. Doktori értekezéstervezet, BCE Információrendszerek Tanszék

(202). Tuásmenedzsment, Prim Online, 09.08 Ford, M. - Hewels, T. (2006): Factors influencing knowledge sharing in information technology projects, e-Service Journal, Vol. 5, No. 1.
Gartner G. (2001): White papers on knowledge management, Gartner Group, Stanford, CT

Garvin, D. A. (1993): Building a Learning Organization, ew, July-August

Gelei A. (2002): A szervezeti tanulás interpretatív megközelítése: A szervezetfejlesztés esete, $\mathrm{PhD}$ disszertáció

Gurteen, $D$. (2008): KM 2.0 - KM goes social. in Inside Knowledge Magazine 2008. feb. 29. Volume 11, Issue 6 ansen, M.T. - Nohria, N. - Tierney, T. (1999): What's your
strategy for managing knowledge? Haward Business strategy for managing
review, Vol. 77, No. 2 .

Herschel, R.T. - Jones N.E. (2005): Knowledge management and business intelligence: the importance of integration, Journal of Knowledge management, Vol. 9, No. 4.

Jewels, T. - Ford, M. (2006): Factors Influencing Knowledge Sharing in Information Technology Projects, e-Service ournal - Vol. 5, No. 1, 2006 ösz, 99-117. o.

Laszlo, A. - Laszlo, K.C. (2002): Evolving knowledge for development: the role of knowledge management in a thanging world, Journal of Knowledge Man Vol. 6, No. 4

\section{JÁNLÁS SZERZŐINKNEK}

A Vezetéstudomány a Budapesti Corvinus Egyetem Corvinus School of

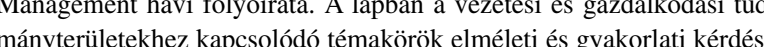
elemző́s vizssgáló írások jelennek meg. A szerkesztớség (robert.becsky@ uni-corvinus.hu) elektronikus formában kéri az írásokat. A cikkeket elekronikus levélben vagy mágneslemezen (MS Word fájil formátumban) lehet a szerkestzőśśghez eljuttatni.

ezért szövegközi forráshivatkozások és ezek jegyzéke nélküili írásokat nem jelentet meg. A Vezetéstudományban meg-
jelentetni szándékozott kéziratok szerzóió̂l az alábbi követelmények figyelembevétélét kérjïk:

A cikkek szokasos terjedelme a hivatkozásokkal, ábrákkal és tábli zatokkal egyuitt 20-24 oldal, 1,5-es sortávolsággal (12-es betúméret, Tszerző foglalkozását, munkahelyét és b címét, a tanulmány elkészítésével kapcsolatos információkat és az esetleges köszönetnyilvánitásokat.

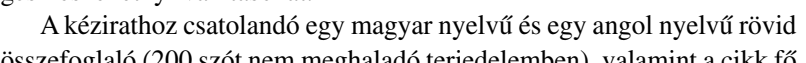
összefoglalá (200 szót nem meghaladó terjedelemben), valamint a cikk tón

Kiemeléshez félkövér és dólt betú használható, aláhhízás nem. Jegyzeteket lehetólég ne hasznájjanak, amenny
sek, szövegvégi jegyzetként adják meg.

A táblázatoknak és ábráknak legyen sorszáma és címe, valamin átvett forrás esetén - pontos hivatkozása. Az ábrákat és a táblázatok catolni, helyiket a š̈veghen egyértelmúen jelölve (pl. Kérem az táblázatot kb. itt elhelyeznil"),

A szzövegkōzi bibliográtiai hivatkozásokat zárójelben, a vezzetékn és az évszám feltüntetésével kérjük jelölni: pl. (Veress, 1999); szó sz

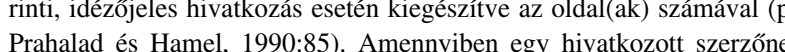
több bibliográfiai tétele van ugyanazon évben, ezeket 1999a, 1999b sb. módon kell megkülönböztetni.

A felhasznált források cikk végén elhelyezett jegyzékét ábécérendb kerjük, a koverkezó formában: Szzerző (evvszám): Cím, kiadás helye: ado; illetve forrás
Martensson, M. (2000): A critical review of knowledge management as a management tool, Journal of Móricz P. (2008): Önzent,

zet- és vezetéselmélet, március 19.

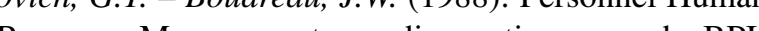
Irwin, Homewood, Illinois

Nonaka, I. - Takeuchi, H.(1995): The knowledge-creating company - how Japanese companies create the dynamics

Wiseman, C. (1988): Strategic Information Systems, Irwin, Chicago (Autumn)

Zuboff, S. (1988): In the Age of the Smart Machine: The Future of Work and Power, Basic Books, New York

Cikk beérkezett: 2008. 6. hó

Lektori vélemény alapján véglegesítve: 2008. 8. hó
1. példa (könyv): Porter, M.E. (1980): Competitive Strategy; New
York: The Free Press. York: The Free Press
példa (folyoiratcikk): Competence of the Corporation; Harvard Business Review, majius-
Celda junius, 79-91. o.

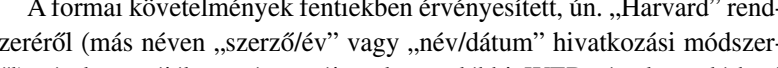
ricészletes tajjékoztatást nyújtanak az alábbi WEB-címeken elérhetô Az elektronikus forrásokra való hivatkozás aktuális probléma. Az Internet Library for Librarians egyik polca (www.tcompany.com/
inforetriever/inetcite.htm) kilenc helyet gyúitotott össze e témával kapcsolatban. Az angolszász országokbban több elterjedt formája van a bibliográtai hivatkozásnak. Ezek a formák több folyóiratban is használatosak. saban ad hasznos tanácsokat a Guide to Citing Internet Sources (www. bournemouth.ac.uk/service-depts/lis/LIS_Pub/harvardsystint.html). A Modern Language Association of America (MLA) - egyébként szintén sok helyuut alkalmazott - hivatkozási stílusával kapcsolatban jánlható az MLA-Style Citations of Electronic Sources (www.cas.usf.

列 zési stílusával foglalkozó forrásokat gyưutiti csokororba.

Havi folyóriat lévén és a megjelenés átutuási idejének csökkentése tedekében a Vezetéstudomány kefelevonatot nem küld, elfogadás elót tozatát.

06 januárjától az ưj lapszámok cikkeit és 2004-ig visszamenóleg az

„,Www.securities.com” internetcénen találhatón strukturált on-line incormációs adatbázisban. Ha a szerzỏ nem járul hozzá cikkének eseti kérésre, elektronikus úton való továbbadásához, kérjük, elóre közö̈jje! 